\title{
The value of epidemiology in headache
}

\author{
Ettore Beghi \\ From Abstracts from the 1st Joint ANIRCEF-SISC Congress \\ Rome, Italy. 29-31 October 2015
}

Headache is the commonest neurological condition worldwide. According to the Global Burden of Disease 2010, tension-type headache is the second most common clinical condition (prevalence, 20.8\%) preceded only by dental caries and followed by migraine (prevalence, 14.7\%) [1]. Globally, migraine is the leading cause of disabilityadjusted life years (DALY) and years living with disability (YLD). This information was obtained from epidemiological studies in developed and in developing countries where well-defined populations were investigated in search of people suffering from headache. Epidemiological studies estimate the frequency, spectrum and burden of a disease in a population. Headache, in this regard, has peculiar aspects that cannot be fully explored when studying referral patients (i.e., individuals seen in hospital, headache centers and other outpatient services) as the majority of patients do not have access to hospital facilities and several individuals do not even ask for medical consultation. However, in light of the frequency of headache in the population, the disease has a high impact on the society in terms of functional disability and indirect costs [2].

As several epidemiological studies are based on telephone interviews, the full spectrum of the disease can be easily captured on a population basis. Epidemiological studies are also instrumental when addressing the role of personal and environmental risk factors and their association with headache (migraine) types [3]. However, the representativeness of the study population is a pre-requisite for the external validity of the results. In addition, in the absence of valid and reliable biomarkers, the diagnosis of headache still relies mostly on clinical findings [4]. In this regard, epidemiology largely contributes to the identification of symptoms and signs most likely to differentiate the main diagnostic categories of the disease.

Published: 28 September 2015

Correspondence: ettore.beghi@marionegri.it

Department of Neuroscience, IRCCS Institute for Pharmacological Research Mario Negri, Milan, Italy

SpringerOpen $^{\odot}$

(0) 2015 Beghi This is an Open Access article distributed under the terms of the Creative Commons Attribution License (http:// creativecommons.org/licenses/by/4.0), which permits unrestricted use, distribution, and reproduction in any medium, provided the original work is properly cited. The Creative Commons Public Domain Dedication waiver (http://creativecommons.org/publicdomain/ zero/1.0/) applies to the data made available in this article, unless otherwise stated.
References
1. Stovner $L$, Hoff JM, Svajheim S, Gilhus NE: Neurological disorders in the Global Burden of Disease 2010 study. Acta Neurol Scand 2014, 129(Suppl 198):1-6.

2. Lanteri-Minet M: Economic burden and costs of chronic migraine. Curr Pain Headache Rep 2014, 18:385.

3. Merikangas KR: Contributions of epidemiology to our understanding of migraine. Headache 2013, 53:230-246.

4. Zhang Y, Kong Q, Chen J, Li L, Wang D, Zhou J: International Classification of Headache Disorders 3rd edition beta-based field testing of vestibular migraine in China: Demographic, clinical characteristics, audiometric findings and diagnosis statues. Cephalalgia 2015, 0333102415587704, [Epub ahead of print].

doi:10.1186/1129-2377-16-S1-A43

Cite this article as: Beghi: The value of epidemiology in headache. The Journal of Headache and Pain 2015 16(Suppl 1):A43.

Submit your manuscript to a SpringerOpen ${ }^{\odot}$ journal and benefit from:

- Convenient online submission

- Rigorous peer review

- Immediate publication on acceptance

- Open access: articles freely available online

- High visibility within the field

- Retaining the copyright to your article

Submit your next manuscript at $\gg$ springeropen.com 